\title{
Craniometrical characteristics of wolves Canis lupus from Poland
}

\author{
Henryk OKARMA and Tadeusz BUCHALCZYK*
}

\begin{abstract}
Okarma H. and Buchalczyk T. 1993. Craniometrical characteristics of wolves Canis lupus from Poland. Acta theriol. 38: $253-262$.

Skulls of 145 adult wolves Canis lupus Linnaeus, 1758 from two areas of the highest wolf density in Poland (78 from the Carpathian Mountains and 71 from the Białowieża Primeval Forest) were measured using 17 selected characters. Values of cranial characters measured were similar to those of previous studies from middleastern Eurasia. Generally, wolf skulls were larger in the mountain than in the lowland population: males from the Carpathian Mountains were larger than that from the Białowieża Forest, however females were slightly smaller than that in the Białowieża Forest. On both areas males were larger than females, but a difference between sexes was much highly pronounced in wolves from the mountain population.

Mammal Research Institute, Polish Academy of Sciences, 17-230 Białowieża, Poland

Key words: Canis lupus, craniometry, skull variability, Poland
\end{abstract}

\section{Introduction}

The wolf Canis lupus Linnaeus, 1758 is the most numerous large carnivore in Poland. For many years it was classified in wildlife management as vermin; only recently has it received increased research interest (see Okarma 1992 for review). Relatively few skulls of wolves have been measured. Sumiński (1975a) measured some wolves' skulls for comparison with those of the domestic dog. Sumiński and Kobryń (1980) tried to determine the sex of wolf skulls using discrimination analysis, and Buchalczyk et al. (1981) described some of the variation in the number of teeth as well the asymmetry of the skull. Buchalczyk (1981) published only the condylobasal length when analysing 16 female and 32 male skulls.

The aim of this study was to describe the basic cranial characters of wolves in Poland, and test for possible differences between the mountain (the Carpathian Mts - CMT) and lowland (the Białowieża Primeval Forest - BPF) wolf populations.

*Present address: Paganiniego 9/34, 20-854 Lublin, Poland 


\section{Materials and methods}

Craniometrical measurements were made of wolf skulls from two distinct areas of Poland: the Carpathian Mountains (southeastern Poland) and the Białowieża Primeval Forest (northeastern Poland). These areas are separated by a distance of approximately $300 \mathrm{~km}$, and both have been inhabited by wolves even in years of low wolf densities (Sumiński 1975b). These populations were isolated from each other for some time (Okarma 1989).

The Carpathian sample consisted of 78 skulls ( 49 males, 29 females). All these skulls came from private hunters' collections and were measured by the first author. Amongst the Białowieża sample of 71 skulls ( 40 males, 31 females), most came from the Belarus part of the Białowieża Primeval Forest complex (measured at the Zoological Museum of the Moscow University by the second author). Previously some of these skulls were measured by Rossolimo and Dolgov (1965). Moreover, small number of skulls came from hunters in the Polish part of the forest and the collection of the Mammal Research Institute PAS, Białowieża (measured by the first author).

Only skulls of adult specimens were measured, because it is not until the adult stage that the maximum size of all major dimensions of the skull is attained (Nowak 1973). The main criterion used to distinguish juveniles and subadults from adults were: complete closure of the basisphenoid-basioccipital suture, tooth wear, the degree of ossification of the cranial sutures, and zygomatic breadth.

The seventeen measurements taken of each complete skull were those described by von den Driesch (1976) (Fig. 1), namely:

1. condylobasal length (aboral border of the occipital condyles - Prosthion) (CbL),

2. breadth of alveolus of the upper canine $C^{1}\left(C^{1} B\right)$,

3. breadth of alveolus of $\mathrm{P}^{4}\left(\mathrm{P}^{4} \mathrm{~B}\right)$,

4. zygomatic breadth (Zygion - Zygion) (ZyB),

5. minimum breadth between the orbits (Entorbitale - Entorbitale) (EntB),

6. maximum frontal breadth (Ectorbitale - Ectorbitale) (EctB),

7. minimum breadth of skull (minimum aboral breadth of the supraorbital processes) (LB),

8. maximum mastoid breadth (Otion - Otion) (MB),

9. skull height (with the sagittal crest) (SH),

10. facial length (Frontal midpoint - Prosthion) (FaL),

11. upper neurocranium length (Frontal midpoint - Opisthion) (NeL),

12. length of tooth-row (from anterior edge of alveola of $\mathrm{C}^{1}$ to posterior edge of alveola of $\mathrm{M}^{2}$ ) (TRL),

13. length of $\mathrm{C}^{1}$ (measured on cingulum) $\left(\mathrm{C}^{1} \mathrm{~L}\right)$,

14. length of $\mathrm{P}^{4}$ (measured on cingulum) $\left(\mathrm{P}^{4} \mathrm{~L}\right)$,

15. total length of mandible (Infradentale - Condyle process) (MdL),

16. height of the vertical ramus of mandible (basal point of the angular process - Coronion) (MdH),

17. length of $M_{1}\left(M_{1} L\right)$.

Measurements of cranial characters were taken with 30-cm-long digimatic caliper to an accuracy of $0.1 \mathrm{~mm}$. Statistical analyses were performed using SPSS MANOVA (SPSS 4.1 Statistical Data Analysis, SPSS Inc., Chicago, IL, 1990) (Tabachnick and Fidell, 1983). Moreover, for each cranial character the coefficient of variation was calculated, and an index of sexual dimorphism according to Storer (1966):

$$
\frac{x_{\mathrm{m}}-x_{\mathrm{f}}}{\left(x_{\mathrm{m}}+x_{\mathrm{f}}\right): 2} \times 100
$$

where: $x_{\mathrm{m}}$ - average value of a character for males, $x_{\mathrm{f}}$ - average value of a character for females. Storer's index varies theoretically from -200 to +200 . Minus values indicated that females are larger than males, 0 that there is no differences between sexes, and plus values that males are larger than females. 

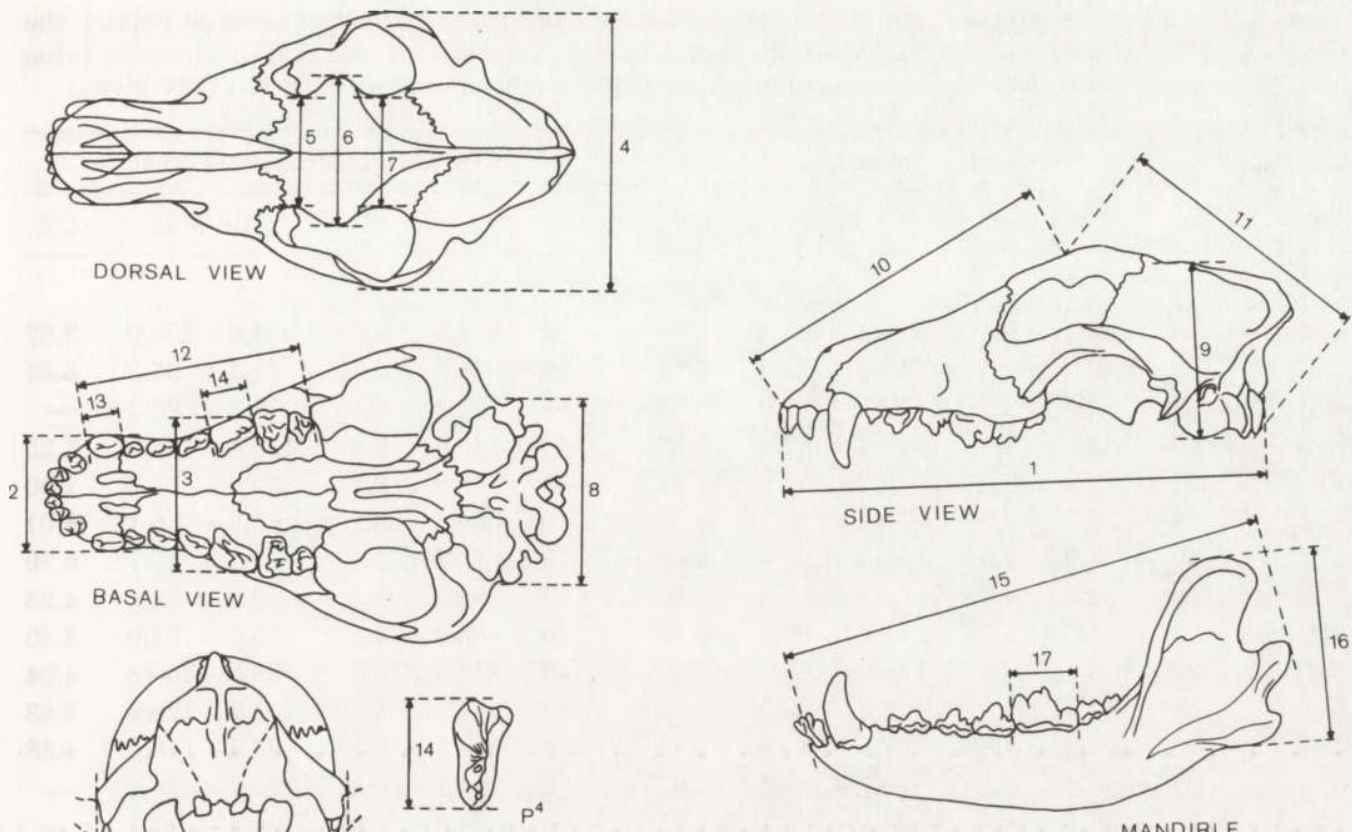

Fig. 1. Description of cranial characters measured. Explanations of numbers in the text.

\section{Results}

Condylobasal length of adult wolf skulls measured ranged from 214.0 to $263.4 \mathrm{~mm}$ (females $216.2-243.0 \mathrm{~mm}$, males $214.0-263.4 \mathrm{~mm}$ ). Zygomatic breadth ranged from 119.3 to $157.7 \mathrm{~mm}$ (females 119.3 - $143.2 \mathrm{~mm}$, males 124.1 - 157.7 $\mathrm{mm}$ ). All cranial characters measured are given in Table 1 .

Coefficients of variation of cranial characters were generally higher in males than in females. In the CMT only coefficients of characters $\mathrm{P}^{4} \mathrm{~L}$ and $\mathrm{M}_{1} \mathrm{~L}$ were higher in females. In the BPF only coefficient of LB was higher in females (Table 1).

Similar group of skull characters varied the most and the least both in the mountain and in lowland populations. The highest coefficients of variation were found in the CMT for characters LB, EctB, $\mathrm{C}^{1} \mathrm{~L}$, EntB (males) and LB, EctB, EntB, $\mathrm{C}^{1} \mathrm{~L}$ (females); while in the BPF for EctB, EntB, MdH, LB (males) and LB, EctB, EntB, $\mathrm{MdH}$ (females). The following coefficients were lowest in mountains: $\mathrm{P}^{4} \mathrm{~B}$, $\mathrm{CbL}, \mathrm{MdL}$ (males) and $\mathrm{CbL}, \mathrm{MdL}, \mathrm{NeL}$ (females); while in lowland: $\mathrm{CbL}, \mathrm{MdL}$, NeL (males) and CbL, MB, MdL (females) (Table 1).

A $2 \times 2$ between subjects multivariate analysis of variance was performed on the thirteen dependent variables: $\mathrm{CbL}, \mathrm{C}^{1} \mathrm{~B}, \mathrm{ZyB}$, EntB, EctB, LB, MB, SH, FaL, NeL, TRL, MdL, and MdH. Four other cranial characters $\left(\mathrm{P}^{4} \mathrm{~B}, \mathrm{C}^{1} \mathrm{~L}, \mathrm{P}^{4} \mathrm{~L}, \mathrm{M}_{1} \mathrm{~L}\right)$ were excluded from analysis since too few data from the lowland population (Table 1). 
Table 1. Skull measurements (in $\mathrm{mm}$ ) of male and female adult wolves from two areas of Poland: the Carpathian Mountains and the Białowieża Primeval Forest. Number of skulls examined, mean value of each measurement, SD, minimum-maximum range, and coefficient of variation $(\mathrm{CV})$ are given

\begin{tabular}{|c|c|c|c|c|c|c|c|c|c|c|}
\hline \multirow{2}{*}{$\begin{array}{l}\text { Measure- } \\
\text { ment }\end{array}$} & \multicolumn{5}{|c|}{ Carpathian Mountains } & \multicolumn{5}{|c|}{ Białowieża Primeval Forest } \\
\hline & $n$ & $\bar{x}$ & SD & Min-Max & CV & $n$ & $\bar{x}$ & $\mathrm{SD}$ & Min-Max & $\mathrm{CV}$ \\
\hline & \multicolumn{10}{|c|}{ Males } \\
\hline $\mathrm{CbL}$ & 49 & 242.1 & 9.4 & $223.4-263.4$ & 3.88 & 40 & 237.8 & 8.5 & $214.0-252.0$ & 3.57 \\
\hline $\mathrm{C}^{1} \mathrm{~B}$ & 49 & 49.2 & 2.5 & $43.2-55.1$ & 5.08 & 40 & 46.5 & 2.7 & $41.6-55.3$ & 5.81 \\
\hline $\mathrm{P}^{4} \mathrm{~B}$ & 49 & 82.7 & 3.1 & $74.5-87.9$ & 3.75 & 6 & 81.4 & 3.4 & $77.7-85.7$ & - \\
\hline ZyB & 49 & 142.6 & 7.5 & $124.1-157.7$ & 5.26 & 40 & 140.6 & 6.4 & $125.4-154.0$ & 4.55 \\
\hline EntB & 49 & 49.1 & 3.0 & $42.7-56.0$ & 6.11 & 40 & 46.8 & 3.7 & $39.0-54.2$ & 7.90 \\
\hline EctB & 49 & 66.7 & 4.9 & $50.4-79.8$ & 7.35 & 40 & 64.6 & 5.2 & $53.3-76.1$ & 8.01 \\
\hline LB & 49 & 44.0 & 4.0 & $38.1-65.4$ & 9.09 & 40 & 42.1 & 2.4 & $36.5-47.7$ & 5.70 \\
\hline MB & 49 & 82.5 & 4.0 & $64.1-90.9$ & 4.85 & 40 & 82.7 & 3.5 & $72.0-88.0$ & 4.23 \\
\hline $\mathrm{SH}$ & 37 & 85.0 & 4.0 & $78.2-93.0$ & 4.70 & 40 & 85.3 & 3.8 & $75.0-94.0$ & 4.45 \\
\hline $\mathrm{FaL}$ & 49 & 148.7 & 6.5 & $136.0-163.7$ & 4.37 & 40 & 148.3 & 6.0 & $135.0-160.3$ & 4.04 \\
\hline $\mathrm{NeL}$ & 49 & 117.1 & 5.3 & $108.0-128.9$ & 4.53 & 40 & 114.9 & 4.4 & $101.7-120.7$ & 3.83 \\
\hline TRL & 49 & 107.3 & 4.8 & $96.5-117.3$ & 4.47 & 39 & 104.5 & 5.1 & $94.4-118.0$ & 4.88 \\
\hline $\mathrm{C}^{1} \mathrm{~L}$ & 49 & 14.4 & 0.9 & $12.7-16.7$ & 6.25 & 6 & 14.1 & 0.4 & $13.7-14.6$ & - \\
\hline $\mathrm{P}^{4} \mathrm{~L}$ & 49 & 26.8 & 1.1 & $24.4-29.2$ & 4.11 & 6 & 25.8 & 1.0 & $24.4-27.1$ & - \\
\hline MdL & 48 & 190.4 & 7.7 & $175.5-207.4$ & 4.00 & 39 & 188.7 & 7.1 & $170.0-202.5$ & 3.76 \\
\hline $\mathrm{MdH}$ & 48 & 76.3 & 3.8 & $70.9-85.2$ & 4.99 & 38 & 75.8 & 4.6 & $67.0-86.2$ & 6.07 \\
\hline \multirow[t]{2}{*}{$\mathrm{M}_{1} \mathrm{~L}$} & 48 & 29.3 & 1.2 & $27.1-32.2$ & 4.09 & 6 & 28.8 & 1.0 & $27.3-30.0$ & - \\
\hline & \multicolumn{10}{|c|}{ Females } \\
\hline $\mathrm{CbL}$ & 29 & 226.1 & 5.8 & $216.2-235.7$ & 2.56 & 31 & 229.4 & 6.3 & $217.0-243.0$ & 2.75 \\
\hline $\mathrm{C}^{1} \mathrm{~B}$ & 29 & 45.5 & 1.7 & $42.3-49.6$ & 3.74 & 31 & 44.9 & 1.9 & $40.7-49.6$ & 4.23 \\
\hline $\mathrm{P}^{4} \mathrm{~B}$ & 29 & 77.5 & 2.6 & $72.3-84.2$ & 3.35 & 3 & 78.5 & 1.4 & $77.3-80.1$ & - \\
\hline $\mathrm{ZyB}$ & 29 & 131.3 & 6.0 & $119.3-142.0$ & 4.57 & 31 & 135.2 & 4.5 & $127.2-143.2$ & 3.33 \\
\hline EntB & 29 & 44.3 & 2.7 & $39.9-49.4$ & 6.09 & 31 & 44.6 & 2.5 & $40.2-50.2$ & 5.60 \\
\hline EctB & 29 & 60.6 & 3.8 & $52.6-66.6$ & 6.27 & 31 & 61.7 & 4.3 & $52.6-72.2$ & 6.97 \\
\hline LB & 29 & 41.3 & 2.6 & $36.4-48.6$ & 6.29 & 31 & 41.9 & 4.8 & $36.9-65.0$ & 11.45 \\
\hline MB & 29 & 79.4 & 2.5 & $73.5-84.9$ & 3.15 & 30 & 79.5 & 2.2 & $75.1-83.9$ & 2.77 \\
\hline $\mathrm{SH}$ & 23 & 80.7 & 2.6 & $74.5-86.8$ & 3.22 & 31 & 82.0 & 2.8 & $78.0-90.0$ & 3.41 \\
\hline $\mathrm{FaL}$ & 29 & 139.8 & 5.5 & $126.0-149.0$ & 3.93 & 31 & 143.5 & 4.1 & $136.2-152.3$ & 2.86 \\
\hline $\mathrm{NeL}$ & 29 & 109.5 & 3.4 & $104.3-117.3$ & 3.10 & 30 & 110.6 & 3.3 & $102.6-117.3$ & 2.98 \\
\hline TRL & 29 & 100.9 & 4.1 & $94.8-116.3$ & 4.06 & 31 & 100.7 & 2.9 & $93.8-106.8$ & 2.88 \\
\hline $\mathrm{C}^{1} \mathrm{~L}$ & 28 & 13.3 & 0.7 & $12.3-14.7$ & 5.26 & 3 & 13.7 & 1.2 & $12.3-14.4$ & - \\
\hline $\mathrm{P}^{4} \mathrm{~L}$ & 29 & 25.2 & 1.3 & $21.1-27.9$ & 5.16 & 3 & 24.7 & 1.1 & $23.4-25.4$ & - \\
\hline MdL & 27 & 176.6 & 5.3 & $165.4-186.0$ & 3.00 & 28 & 180.8 & 5.2 & $168.0-190.0$ & 2.89 \\
\hline $\mathrm{MdH}$ & 27 & 70.2 & 3.0 & $65.0-77.1$ & 4.27 & 27 & 71.0 & 3.3 & $63.2-76.3$ & 4.65 \\
\hline $\mathrm{M}_{1} \mathrm{~L}$ & 28 & 27.7 & 1.2 & $24.6-30.5$ & 4.33 & 2 & 26.6 & 0.5 & $26.3-27.0$ & - \\
\hline
\end{tabular}

With the use of Wilks' criterion, the combined dependent variables were significantly affected by sex, $\mathrm{F}(13,104)=7.20, p<0.001$; geographical location, $\mathrm{F}(13,104)=4.87, p<0.001$; and by their interaction, $\mathrm{F}(13,104)=2.32, p<0.01$. 
Table 2. Tests of geographical location, sex, and their interaction.

\begin{tabular}{|c|c|c|c|c|}
\hline $\begin{array}{l}\text { Independent } \\
\text { variable }\end{array}$ & $\begin{array}{l}\text { Dependent } \\
\text { variable }\end{array}$ & $\begin{array}{l}\text { Univariate } \\
\qquad \mathrm{F}\end{array}$ & df & $\begin{array}{c}\text { Significance } \\
\text { level }\end{array}$ \\
\hline Location & $\begin{array}{l}\mathrm{CbL} \\
\mathrm{C}^{1} \mathrm{~B} \\
\mathrm{ZyB} \\
\text { EntB } \\
\text { EctB } \\
\mathrm{LB} \\
\mathrm{MB} \\
\mathrm{SH} \\
\mathrm{FaL} \\
\mathrm{NeL} \\
\mathrm{TRL} \\
\mathrm{MdL} \\
\mathrm{MdH}\end{array}$ & $\begin{array}{r}0.27 \\
17.17 \\
0.09 \\
4.16 \\
0.34 \\
0.74 \\
0.10 \\
1.31 \\
1.99 \\
1.12 \\
4.69 \\
0.19 \\
0.11\end{array}$ & 1,116 & $\begin{array}{l}.603 \\
.000 \\
.769 \\
.044 \\
.559 \\
.393 \\
.750 \\
.255 \\
.161 \\
.291 \\
.032 \\
.663 \\
.741\end{array}$ \\
\hline Sex & $\begin{array}{l}\mathrm{CbL} \\
\mathrm{C}^{1} \mathrm{~B} \\
\mathrm{ZyB} \\
\text { EntB } \\
\text { EctB } \\
\mathrm{LB} \\
\mathrm{MB} \\
\mathrm{SH} \\
\mathrm{FaL} \\
\mathrm{NeL} \\
\text { TRL } \\
\text { MdL } \\
\text { MdH }\end{array}$ & $\begin{array}{r}70.56 \\
49.53 \\
63.58 \\
33.83 \\
25.20 \\
2.66 \\
23.17 \\
32.20 \\
50.79 \\
61.57 \\
39.06 \\
80.94 \\
57.46\end{array}$ & 1,116 & $\begin{array}{l}.000 \\
.000 \\
.000 \\
.000 \\
.000 \\
.106 \\
.000 \\
.000 \\
.000 \\
.000 \\
.000 \\
.000 \\
.000\end{array}$ \\
\hline $\begin{array}{l}\text { Location by sex } \\
\text { interaction }\end{array}$ & $\begin{array}{l}\mathrm{CbL} \\
\mathrm{C}^{1} \mathrm{~B} \\
\mathrm{ZyB} \\
\text { EntB } \\
\text { EctB } \\
\mathrm{LB} \\
\mathrm{MB} \\
\mathrm{SH} \\
\mathrm{FaL} \\
\mathrm{NeL} \\
\mathrm{TRL} \\
\mathrm{MdL} \\
\mathrm{MdH}\end{array}$ & $\begin{array}{r}8.52 \\
10.44 \\
9.57 \\
3.93 \\
3.09 \\
3.16 \\
0.17 \\
0.53 \\
6.55 \\
3.51 \\
1.95 \\
7.51 \\
1.88\end{array}$ & 1,116 & $\begin{array}{l}.004 \\
.002 \\
.002 \\
.050 \\
.082 \\
.078 \\
.682 \\
.468 \\
.012 \\
.063 \\
.165 \\
.007 \\
.173\end{array}$ \\
\hline
\end{tabular}

Generally, wolf skulls were larger in the mountain than in the lowland population (Table 1 ), however statistically significant differences $(p<0.05)$ were found only for $\mathrm{C}^{1} \mathrm{~B}$, EntB, and TRL (Table 2). Generally, males were larger than 
Table 3. Differences in skull measurements of wolves between adult males and females from the Carpathian Mountains and the Białowieża Primeval Forest. Mean value of each measurement (in mm) for males and females, statistical difference between them $\left({ }^{*}-p<0.05,{ }^{* *}-p<0.001\right)$, and Storer's index of sexual dimorphism are given.

\begin{tabular}{|c|c|c|c|c|c|c|c|}
\hline \multicolumn{4}{|c|}{ Carpathian Mountains } & \multicolumn{4}{|c|}{ Białowieża Primeval Forest } \\
\hline $\begin{array}{l}\text { Measu- } \\
\text { rement }\end{array}$ & Males & Females & $\begin{array}{c}\text { Storer's } \\
\text { index }\end{array}$ & $\begin{array}{l}\text { Measu- } \\
\text { rement }\end{array}$ & Males & Females & $\begin{array}{c}\text { Storer's } \\
\text { index }\end{array}$ \\
\hline $\mathrm{CbL}^{* * *}$ & 242.1 & 226.1 & 6.8 & $\mathrm{CbL}^{* *}$ & 237.8 & 229.4 & 3.6 \\
\hline $\mathrm{C}^{1} \mathrm{~B}^{* *}$ & 49.2 & 45.5 & 7.8 & $\mathrm{C}^{1} \mathrm{~B}^{*}$ & 46.5 & 44.9 & 3.5 \\
\hline $\mathrm{P}^{4} \mathrm{~B}^{* * *}$ & 82.7 & 77.5 & 6.5 & $\mathrm{P}^{4} \mathrm{~B}$ & 81.4 & 78.5 & - \\
\hline ZyB** & 142.6 & 131.3 & 8.2 & ZyB** & 140.6 & 135.2 & 3.9 \\
\hline EntB** & 49.1 & 44.3 & 10.3 & EntB* & 46.8 & 44.6 & 4.8 \\
\hline EctB** & 66.7 & 60.6 & 9.6 & EctB* & 64.6 & 61.7 & 4.6 \\
\hline $\mathrm{LB}^{*}$ & 44.0 & 41.3 & 6.3 & LB n.s. & 42.1 & 41.9 & 0.5 \\
\hline MB** & 82.5 & 79.4 & 3.8 & $\mathrm{MB}^{* *}$ & 82.7 & 79.5 & 3.9 \\
\hline $\mathrm{SH}^{* *}$ & 85.0 & 80.7 & 5.2 & $\mathrm{SH}^{* * *}$ & 85.3 & 82.0 & 3.9 \\
\hline FaL** & 148.7 & 139.8 & 6.2 & FaL** & 148.3 & 143.5 & 3.3 \\
\hline $\mathrm{NeL}^{* *}$ & 117.1 & 109.5 & 6.7 & $\mathrm{NeL}^{* *}$ & 114.9 & 110.6 & 3.8 \\
\hline TRL ** & 107.3 & 100.9 & 6.1 & TRL** & 104.5 & 100.7 & 3.7 \\
\hline $\mathrm{C}^{1} \mathrm{~L}^{* *}$ & 14.4 & 13.3 & 7.9 & $\mathrm{C}^{1} \mathrm{~L}$ & 14.1 & 13.7 & - \\
\hline $\mathrm{P}^{4} \mathrm{~L}^{* *}$ & 26.8 & 25.2 & 6.2 & $\mathrm{P}^{4} \mathrm{~L}$ & 25.8 & 24.7 & - \\
\hline $\mathrm{MdL}^{* *}$ & 190.4 & 176.6 & 7.5 & MdL** & 188.7 & 180.8 & 4.3 \\
\hline $\mathrm{MdH}^{* *}$ & 76.3 & 70.2 & 8.3 & $\mathrm{MdH}^{* *}$ & 75.8 & 71.0 & 6.5 \\
\hline $\mathrm{M}_{1} \mathrm{~L}^{* *}$ & 29.3 & 27.7 & 5.6 & $\mathrm{M}_{1} \mathrm{~L}$ & 28.8 & 26.6 & - \\
\hline
\end{tabular}

Table 4. Selected skull indexes (in \%) of wolves from the Carpathian Mountains (CMT) and the Białowieża Primeval Forest (BPF).

\begin{tabular}{|c|c|c|c|c|c|}
\hline \multirow{2}{*}{ Index } & \multicolumn{2}{|c|}{ Males } & \multirow{2}{*}{ Index } & \multicolumn{2}{|c|}{ Females } \\
\hline & CMT & BPF & & CMT & BPF \\
\hline $\mathrm{C}^{1} \mathrm{~B} / \mathrm{CbL} \times 100 \%$ & 20.3 & 19.5 & $\mathrm{ZyB} / \mathrm{CbL} \times 100 \%$ & 58.1 & 54.6 \\
\hline EntB/CbL $\times 100 \%$ & 20.3 & 19.7 & $\mathrm{FaL} / \mathrm{CbL} \times 100 \%$ & 61.8 & 62.5 \\
\hline $\mathrm{LB} / \mathrm{CbL} \times 100 \%$ & 18.2 & 17.7 & $\mathrm{MdL} / \mathrm{CbL} \times 100 \%$ & 78.1 & 78.8 \\
\hline $\mathrm{TRL} / \mathrm{CbL} \times 100 \%$ & 44.3 & 43.9 & $\mathrm{ZyB} / \mathrm{FaL} \times 100 \%$ & 93.9 & 94.4 \\
\hline $\mathrm{EntB} / \mathrm{C}^{1} \mathrm{~B} \times 100 \%$ & 99.8 & 100.6 & $\mathrm{ZyB} / \mathrm{MdL} \times 100 \%$ & 74.3 & 74.8 \\
\hline $\mathrm{LB} / \mathrm{C}^{1} \mathrm{~B} \times 100 \%$ & 89.4 & 90.5 & $\mathrm{FaL} / \mathrm{MdL} \times 100 \%$ & 79.2 & 79.4 \\
\hline $\mathrm{C}^{1} \mathrm{~B} / \mathrm{TRL} \times 100 \%$ & 45.8 & 44.5 & & & \\
\hline $\mathrm{LB} / \mathrm{EntB} \times 100 \%$ & 89.6 & 89.9 & & & \\
\hline EntB/TRL $\times 100 \%$ & 45.7 & 44.8 & & & \\
\hline $\mathrm{LB} / \mathrm{TRL} \times 100 \%$ & 41.0 & 40.3 & & & \\
\hline
\end{tabular}

females and differences between them were statistically significant for all but one (LB) cranial characters analyzed (Table 2). Six cranial characters (CbL, C ${ }^{1} \mathrm{~B}, \mathrm{ZyB}$, 
EntB, FaL, MdL) showed statistically significant interactions between location and sex: males were larger in the $\mathrm{CM}$ than in the $\mathrm{BPF}$, while females were larger in the BPF than in the CM (Table 2). Both in the CMT and in the BPF, among the adult wolf skulls measured males were larger than females with respect to all 17 cranial characters. In the CMT differences between sexes were statistically significant for all cranial characters (Table 3 ). In the BPF differences in characters $\mathrm{P}^{4} \mathrm{~B}$, $\mathrm{C}^{1} \mathrm{~L}, \mathrm{P}^{4} \mathrm{~L}$, and $\mathrm{M}_{1} \mathrm{~L}$ were not calculated because sample size was too small. For other cranial characters except LB differences between sexes were statistically significant. The mean Storer's index for all cranial characters was 7.1 in the CMT and 3.9 in the BPF (Table 3).

Measurements which statistically differentiated males and females were used to compute basic skull indexes to reveal possible differences in relative proportions of skulls between two studied populations. Indexes calculated were nearly identical for males from the CMT and BPF, and for females from these areas (Table 4).

\section{Discussion}

Values of cranial characters of adult wolves measured in this study (Table 1) were similar to those of previous studies conducted in the middleastern Eurasia. For example Gavrin and Donaurov (1954) found that condylobasal length of wolves from the Belarus part of the Białowieża Primeval Forest was $218.0-253.0 \mathrm{~mm}$ (males) and $207.0-242.0 \mathrm{~mm}$ (females). Rossolimo and Dolgov (1965) stated that mean condylobasal length of skull from various wolf populations inhabited forested zone of the former Soviet Union (USSR) was 235.25 - $248.45 \mathrm{~mm}$ (males) and 229.49 - $235.69 \mathrm{~mm}$ (females). Hell and Paule (1982) reported that the mean condylobasal length of the adult wolf skull from the Slovakian Carpathians was $232.7 \mathrm{~mm}$ (males) and $221.3 \mathrm{~mm}$ (females), and the mean zygomatic breadth 140.7 and $131.8 \mathrm{~mm}$, respectively. Wolf skulls measured in this study, both from the CMT and the BPF, exceed these dimensions both for males and females (Table 1).

In the most comprehensive study from the USSR (the European part of that country), Ševčenko and Borisovec (1988) compared wolf skulls from three areas: steppe zone, forest zone, and the Carpathian Mountains. The mean condylobasal length of male skulls was largest in the steppe zone $(239.1 \mathrm{~mm}$, range $212.0-$ $259.0 \mathrm{~mm}$ ), and of female skulls was in the forest zone $(226.57 \mathrm{~mm}$, range 206.0 $-240.0 \mathrm{~mm}$ ). In the males, condylobasal length of this sample was less than that of skulls from the CMT, but larger than that from the BPF. In females, it was larger than that of skulls from the CMT, but smaller than that from the BPF.

Wolves from southern Europe, Israel, Arabian Peninsula and Iraq are much smaller than those measured in this study. Valverde and Hidalgo (1974) reported that condylobasal length of wolves from Spain was $202-224 \mathrm{~mm}$ (females) and $200-243.5 \mathrm{~mm}$ (males). In Israel condylobasal length of females was $175.5-$ 
Table 5. Maximal condylobasal length (CbL) of wolf skulls from Eurasia.

\begin{tabular}{lcll}
\hline Location & CbL (in mm) & \multicolumn{1}{c}{ Source } \\
\hline 1. European part and northern Asia of the former USSR & 262.0 & Ognev 1931, Novikov 1956 \\
2. Belarus part of the Białowieża Primeval Forest & 253.0 & Gavrin and Donaurov 1954 \\
3. Forest zone of the former USSR & 244.95 & Rossolimo and Dolgov 1965 \\
4. Western Carpathians & 253.0 & Hell 1972 \\
5. Taymyr peninsula (northern Russia) & 271.0 & Bibikov 1985 \\
6. European part of the former USSR & 259.0 & Ševčenko and Borisovec 1988 \\
7. Poland & 257.0 & Buchalczyk 1984 \\
8. Poland (Carpathian Mountains) & 263.4 & this study \\
\hline
\end{tabular}

$211.5 \mathrm{~mm}$, and males 186.3 - $218.4 \mathrm{~mm}$ (Mendelssohn 1982). For the Arabian Peninsula and Iraq this cranial character was even lower $(169-214 \mathrm{~mm})$ as reported by Harrison (1968).

The maximum condylobasal length of the wolf skull found in this study is larger than that previously reported for Poland $(257 \mathrm{~mm}$ ) by Buchalczyk (1984). It is also one of the largest condylobasal length found in Eurasia (Table 5). In North America similarly large skulls can be found in Alaska (Young and Goldman 1944).

Minimal values of cranial characters measured in this study are higher that values found in previous studies (especially Hell 1972). Such low values reported by other authors could be a result of higher proportion of skulls from younger adult specimens or/and insufficient rigor in selecting "adult" skulls.

Coefficients of variation of cranial characters measured were generally higher in males than females (Table 1). This findings does not support results of Hell and Paule (1982), who found that about a half from 23 characters measured was higher in females. The highest variation of EctB, EntB, and LB confirm entirely findings of Hell (1972), similarly as the lowest variation of $\mathrm{CbL}$ and MB.

Among the adult wolf skulls measured, both in the CMT and the BPF, pronounced sexual dimorphism was found. Skulls of females were smaller than those of males in respects of all 17 cranial characters. This is consistent with previous studies both Euroasiatic and North American wolves (Ognev 1931, Young and Goldman 1944, Gavrin and Donaurov 1954, Valverde and Hidalgo 1974, Hell and Paule 1982, Ševčenko and Borisovec 1988).

Sexual dimorphism was much more pronounced among wolves from the CMT: differences between sexes (for all but one measurement - MB) were larger than among wolves from the BPF (Table 3).

It is interesting that males from the Carpathians were larger that males from the BPF, while females from the mountains were smaller than those from the lowlands: only 4 out of 17 characters measured $\left(C^{1} B\right.$, TRL, $\left.P^{4} L, M_{1} L\right)$ were larger in the Carpathians than in the Białowieża (Table 1). We could not find any reasonable explanation of this phenomenon. 
Calculated skull indexes were similar for males and for females in both study areas (Table 4). It showed that, in respect of these indexes, the relative proportions of wolf skulls were similar in the Carpathians and in the Białowieża Forest for both sexes.

Acknowledgements: We thank Prof Z. Pucek for critical comments to this manuscript, Dr W. Jędrzejewski for statistical advices and Dr P. Scanlon for correcting the English.

\section{References}

Bibikov D. I. 1985. [The wolf]. Izd. Nauka, Moskva: 1 - 606. [In Russian]

Buchalczyk T. 1981. Order: Carnivores - Carnivora. [In: Keys to vertebrates of Poland Mammals. Z. Pucek, ed]. PWN - Polish Scientific Publishers, Warsaw: 260 - 306.

Buchalczyk T., Dynowski J. and Szteyn S. 1981. Variations in number of teeth and asymmetry of the skull in the wolf. Acta theriol. 26: $23-30$.

Driesch A. von den 1976. A guide to the measurement of animal bones from archaeological sites. Peabody Museum Bull. 1: 1 - 137.

Gavrin V. F. and Donaurov S. S. 1954. [The wolf in the Białowieża Forest]. Zool. Ž. 33(4): $904-924$. [In Russian]

Harrison D. L. 1968. The mammals of Arabia. Ernest Bern Ltd, London: 2: $193-381$.

Hell P. 1972. [On craniometrical studies of the wolf from western Carpathians]. Lynx, S.N. 13: 5 - 14 . [In Czech]

Hell P. and Paule L. 1982. Ergebnisse taxonomischer Untersuchungen des Wolfes (Canis lupus) in den slowakischen Karpaten. Folia zool. 31: $255-270$.

Mendelssohn H. 1982. Wolves in Israel. [In: Wolves of the world. F. H. Harrington and P. C. Paquet, eds]. Noyes Publications, Park Ridge, New Jersey: 173 - 195.

Nowak R. 1973. North American Quaternary Canis. Ph.D. thesis, University of Kansans.

Novikov G. A. 1956. [Carnivorous mammals of USSR]. AN SSSR, Moskva: 1 - 293. [In Russian]

Ognev S. J. 1931. Mammals of eastern Europe and northern Asia. [Israel Program for Scient. Transl., Jerusalem 1962] 2: 1 - 277 .

Okarma H. 1989. Distribution and number of wolves in Poland. Acta theriol. 34: $497-503$.

Okarma H. 1992. [The wolf - the monograph of a species]. Białowieża: 1 - 168. [In Polish with a chapter in English - The wolf in Poland]

Rossolimo O. L. and Dolgov V. A. 1965. Variability of the skull in Canis lupus Linnaeus, 1758 from the USSR. Acta theriol. 10: 195 - 207. [In Russian with English summary]

Storer R. W. 1966. Sexual dimorphism and food habits in three North American accipiters. Auk 83: $423-436$.

Sumiński P. 1975a. Vergleichende Untersuchungen zwischen dem Wolfsschädel (Canis lupus L.) und dem Hundeschädel (Canis familiaris L.). Z. Jagdwiss. 21: 129 - 133.

Sumiński P. 1975b. The wolf in Poland. Proc. of the $1^{\text {st }}$ Meeting of Wolf Specialists and of the $1^{\text {st }}$ International Conference on the Conservation of the Wolf. Stockholm, 1973. IUCN Publications New Series, Morges, Suppl. Paper No. 43: $44-52$.

Sumiński P. and Kobryń K. 1980. Auswertung der Brauchbarkeit einer Diskriminationsanalysenmethode zur Geschlechtsbestimmung der Wolfsschädel (Canis lupus L. 1758). Z. Jagdwiss. 26: $121-126$.

Ševčenko L. S. and Borisovec B. E. 1988. [Interspecific structure of carnivorous mammals of European part of USSR]. Vestnik Zool. 88; 6: $32-43$. [In Russian]

Tabachnick B. G. and Fidell L. S. 1983. Using multivariate statistics. Harper and Row, Publishers, New York: $1-509$. 
Valverde J. A. and Hidalgo A. 1974. Sobre al Lobo (Canis lupus) ibérico: I. Dimorfismo sexual en cráneos. Doñana, Acta Vert. I(2): 233 - 244.

Young S. P. and Goldman E. A. 1944. The wolves of North America. Am. Wildl. Inst., Washington: $1-385$.

Received 27 November 1992, revised 24 August 1993, accepted 30 September 1993. 